\title{
Structural Policies and Growth: \\ Time Series Evidence from a Natural Experiment
}

\author{
Theo Eicher \\ University of Washington \\ Ifo Institute of Economic Research
}

Till Schreiber

College of William and Mary

\begin{abstract}
College of William and Mary
Department of Economics

Working Paper Number 48
\end{abstract}

November 2006

We thank two referees for extensive and insightful questions, the editor, Daron Acemoglu, for guidance and comments, and Sascha Becker, Christa Heinz, Stephan Klasen, Charles Nelson, Chris Papageorgiou, Richard Startz, Judy Thornton, Farid Toubal, Steve Turnovsky, and especially John Temple for helpful comments. Any remaining errors are our own. Theo Eicher thanks the German Science Foundation for financial support. 
COLLEGE OF WILLIAM AND MARY

DEPARTMENT OF ECONOMICS

WORKING PAPER \# 48

November 2006

\title{
Structural Policies and Growth: Time Series Evidence from a Natural Experiment
}

\begin{abstract}
Documenting the long term impact of structural policies on economic performance has generated tremendous interest in the development literature. In contrast, contemporary effects of structural policies are difficult to establish. Structural policies seldom change sufficiently in the short run, and accepted instruments to control for endogeneity in cross sections are inappropriate for time series analysis. In this paper we utilize an eleven year panel of 26 transition countries to identify short term effects of structural policies that are large and significant. A ten percent change in the quality of structural policies (or the Rule of Law) towards OECD standards is shown to raise annual growth by about 2.5 percent. To control for endogeneity, we instrument using the hierarchy of institutions hypothesis and find that it holds robust explanatory power. We also document that early reformers reap the greatest benefits, but that it is never too late to begin structural policy reforms.
\end{abstract}

JEL Codes: O40, P48, O11

Keywords: structural policies, growth, dynamic panel, transition economies

Theo Eicher

Department of Economics

University of Washington

Seattle, WA 98195

USA

te@u.washington.edu
Till Schreiber

Department of Economics

College of William and Mary

Williamsburg, VA 23187-8795

USA

txschr@wm.edu 


\section{I) Introduction}

A growing strand of the empirical growth literature focuses on the explanatory power of structural policies or institutions to account for differences in living standards across countries. ${ }^{1}$ In general, structural policies evolve slowly, and empirical studies focus on their long term influences on income levels (e.g., Hall and Jones 1999 and Acemoglu et al. 2001). ${ }^{2}$ Instead of examining long term effects of structural policies that are captured in cross sections, we investigate their contemporary short term effects on economic growth in a panel of countries.

Two issues have prevented researchers from identifying the growth effects of structural policies. A panel approach requires sufficiently large variation not only in structural policies, but also in the relevant instruments that are necessary to control for endogeneity. Generally this variation does not exist in the data. We resolve both issues by utilizing the fall of the Iron Curtain as a natural experiment that allows us to examine how communist-to-capitalist system changes are associated with rapid changes in structural policies that catch up to OECD standards. The fall of the Iron Curtain provides a unique controlled, or natural, experiment in that the initial institutional change is clearly exogenous, which potentially mitigates the endogeneity bias. It also provides a unique opportunity to analyze the impact of subsequent structural policy changes on growth in a sizeable number of countries, with similar initial conditions, over the same period of time.

The overriding feature in our panel is change in three dimensions. First, we observe diverse patterns of output changes over time. Second, structural policies evolved at varying speeds as countries transitioned from centrally-planned towards market-based systems. Third, political institutions moved progressively, and again at varying speeds, from autocracy to democracy after the fall of one-party regimes. The differential performances in transition countries have been closely linked to differences in institutions or structural policies across countries. ${ }^{3}$ However, there is no inherent reason to expect a contemporary effect of structural policies on economic performance. Institutions or structural policies are usually seen as persistent, but this specific period and set of countries provides an excellent example of what North (1990) coined "discontinuous institutional change." The approach has been formalized by Krasner (1993) and Norris (1997) in a "punctuated institutional equilibrium" that describes institutions in long periods of stasis, interrupted by crises that bring about abrupt change.

\footnotetext{
1 The literature also uses the terms "economic institutions," "reforms," "structural reforms," "structural policies," "growth promoting policies," and "social infrastructure." For a discussion of the terminology, please see Section 2.

${ }^{2}$ For example, the type of colonial history is shown to impact current institutions and thus current output levels.

${ }^{3}$ We discuss the literature in detail in Section 1 below.
} 
The endogeneity of institutions or structural policies raises serious econometric issues that have been amply documented in the previous literature (See Acemoglu 2005 for a survey). Fixed effects panel analysis cannot utilize the established cross-sectional instruments such as latitude, language, settler mortality, or any other history-based variables. Our task is to identify new instruments that are uncorrelated with the disturbances, but that vary sufficiently over time to isolate the effects of ongoing institutional change on economic performance. Our strategy is two-pronged. On the one hand, we use the system GMM estimator, which Blundell and Bond (1998), Bond, Hoeffler, and Temple (2001), and Bond (2002) argue to be unbiased in the presence of endogenous independent variables when lags go beyond 2 (we use lags 3 to 5). Alternatively, we develop instruments using the hierarchy of institutions hypothesis (Williamson 2000, Acemoglu et al. 2005, and Roland 2004) to address endogeneity. Here the notion is that political institutions are critical determinants of economic institutions or structural policies, which subsequently determine economic outcomes. Hence political institutions could theoretically function as instruments in our analysis.

In the tradition of the long run institutions literature, we first report cross section results that establish the importance of the initial quality level of structural reforms on subsequent income and growth. ${ }^{4}$ Then we use panel analysis to examine the impact of short term effects of structural policies across economies. Even after controlling for endogeneity, the contemporaneous effect of structural policies on growth is shown to be large. For example, a ten percent improvement in institutions is shown to raise the annual growth rate by about 2.7 percent in the panel. This result is remarkably robust to a variety of different specifications, including changes in the time horizon, averaging over time periods, using transition time, the use of alternative instruments, or institution measures.

The specific set of countries in our panel has been the subject of extensive theoretical and empirical studies. Aghion and Blanchard (1994), Kornai (1994), Blanchard (1997), Blanchard and Kremer (1997), and Roland (2000) provide theories of growth, U-shaped output responses, market imperfections, and the reallocation of resources within/between public/private sectors in transition economies. A rich empirical literature uses EBRD indices and the similar (and earlier) De Melo et al. (1997) liberalization index to access determinants of transition performance. De Melo et al. (2001), Aslund et al. (1996), Fischer et al. (1996a,b), and Selowsky and Martin (1997) analyze the impact of the cumulative De Melo et al. (1997) index on growth, interpreting

\footnotetext{
${ }^{4}$ See also Knack and Keefer (1995) and Barro (1997) among numerous studies for OLS growth regressions that include institution indices. For a review of the role of initial conditions in transition economies, see Murrell (1996).
} 
it as a measure of the speed of reform. Havrylyshyn, van Rooden, and Izvorski (1998), Berg et al. (1999), Havrylyshyn and van Rooden (2003), use ERBD and De Melo et al (1997) indices together with policy variables (inflation and fiscal deficits) to find that their combination explains most of the variation in transition growth.

Initial studies focus on cross sections or short panels, assuming a one-way causation from structural policies to growth. Wolf (1999) controls for the endogeneity of policy variables and Heybey and Murrell (1999) (in a cross section) and Falcetti et al. (2002) (in a panel) estimate a simultaneous system to allow feedback via structural reforms that are instrumented with one period lags. Berg et al. (1999) and Ghosh (1997) instrument stabilization policies whose significance was highlighted by Kornai (1994). Beck and Laeven (2006) use natural resource endowments and time under communism as instruments for initial conditions. Their results show significant feedbacks and large differences compared to OLS regressions.

Our paper features three distinct departures from the previous literature. First, we present long time series that allow us to apply formal econometric methods to address endogeneity. Second, we use theory-based instruments to control for endogeneity. Finally, instead of a Barro (1997) approach that establishes an exhaustive list of growth determinants, we follow Hall and Jones (1999) and Acemoglu et al. (2001) and focus only on the impact of institutions. This is not meant to detract from alternative explanations, variables, or approaches; it is simply an attempt to capture and highlight the aspects of institutional change. Our robustness checks also consider alternative contemporaneous growth determinants. Much like Acemoglu et al. (2003), we find that structural policies dominate.

\section{2) Data}

We examine the impact of structural policies and the rule of law on real per capita GDP growth between 1991 and 2001 for 26 transition economies (Figure A1). Since eight of these countries concluded their EU accession negotiations in 2002, we end our analysis in 2001 to avoid potential structural breaks. Below we simply refer to "structural policies," although Persson (2005) highlights that the literature's focus on "institutions" often associates identical measures with different labels. Hall and Jones (1999) use "social infrastructure," Acemoglu, Johnson, and Robinson (2005) refer to "economic institutions," Rodrik, Subramanian, and Trebbi, (2004) simply say "institutions," while Persson (2005) uses "growth promoting policies" or "structural 
policies." All of these terms are used to refer to identical or very similar fundamental data (specifically ICRG measures of property rights protection and/or openness).

Time series for these traditional proxies of structural policies do not exist for transition economies. Instead the components of the EBRD liberalization index were designed to capture "the task of building market-supporting institutions" (EBRD 1994, Chapter 1). We utilize these EBRD (2000, 2001, 2002) measures to construct a Structural Policy Index (see Figure A1), consisting of price liberalization, foreign exchange/trade liberalization, small/large scale privatization, enterprise reform, competition policy reform, banking sector reform, and reform of non-banking financial institutions. Since the individual components are highly correlated, we follow Hall and Jones (1999) and sum all into one composite index that is normalized to a range from zero to unity (1 = OECD quality).

Fisher and Sahay (2004) use the identical index as "measures of the extent and success of the institution building that took place in the last decade" in transition countries. Most recently, Roland (2005) uses the exact same subindices as "institutional indicators" to graphically assess progress in "institutional transition" in new EU member countries from 1991 to 1999. Clearly the structural policy index only proxies economic institutions and does not represent them. The index is highly correlated with the ICRG government anti-diversion index (for the overlapping years, in 19 countries, the correlation is $=0.7$ ). As an alternative structural policy index, we also use an ICRG-based Rule of Law measure. A complete ICRG time series exist for only seven transition countries. Partial time series exist for 18 other countries. We extend the ICRG index by using countries with overlapping years to estimate a fit of Campos' (2000) Rule of Law index into the ICRG index. Campos' (2000) criteria for establishing Rule of Law are identical to ICRG's.

In our search for alternative instruments we utilize common proxies for political institutions, specifically "Executive Constraints" and "Democracy" variables from Polity IV that reflect de facto independence of the executive branch and the degree of democratic institutions, respectively. We also use the related "Check and Balances" and "Executive Indices of Electoral Competitiveness" from the World Bank database of political institutions (Beck et al. 2001) for robustness checks. Finally, macro policy variables (fiscal deficit, government consumption, and inflation) are added in further robustness exercises and are obtained from EBRD (2005). 


\section{3) Exploratory Cross-Country Regressions}

While we are ultimately interested in the time series implications of structural policies, we commence by examining the effects of initial conditions on long run economic performance. This exploration acknowledges a large literature that concentrates on the significance of initial conditions in the transition process. Reviewing the transition literature, Murrell (1996) suggests that political change and institutional change are both related to initial conditions. ${ }^{5}$

Figures $1 \mathrm{a}$ and $1 \mathrm{~b}$ show the positive correlation between structural policies and standards of living across countries. In 1991 there already existed considerable variation in structural policies across countries in our sample, indicating diverse initial conditions. The figures also highlight that the change in structural policies was not constant across countries. By 2001 some initial laggards (Estonia, Lithuania, and Latvia in particular) had made substantial progress towards OECD quality structural policies. But six of the 26 countries did not even achieve a 0.5 rating by 2001. A possible mean reversion argument can be ruled out from Figure 1. Clearly, many of the early frontrunners are still the most advanced countries 11 years later. Many countries in the Former Soviet Union which started at 0 in 1991 are still below average in 2001.

\section{Effects of Initial Conditions and Structural Policies on Economic Performance}

Figure 1a

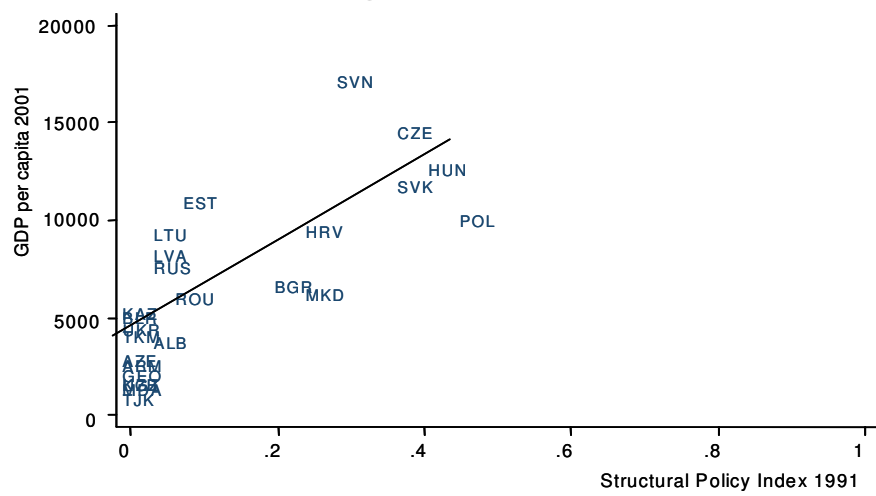

Figure 1b

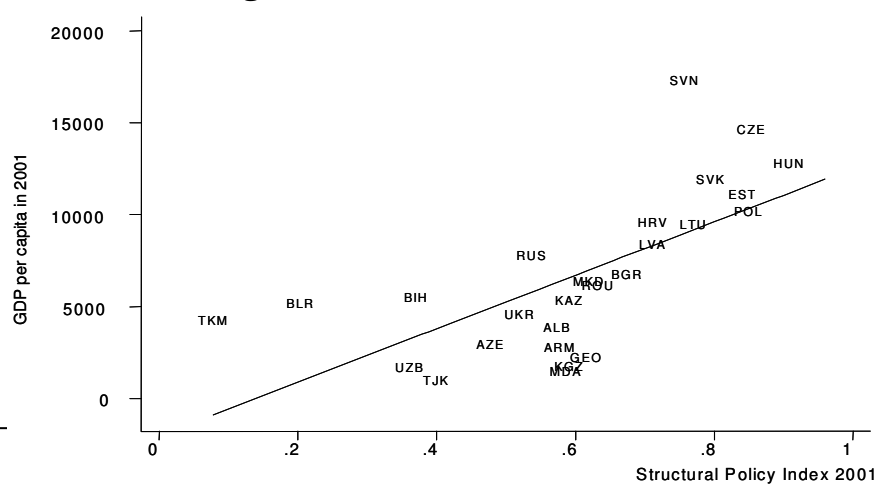

We augment Figure 1a-b with two-stage least squares estimations that address endogeneity. In the spirit of instruments that identify the impact of "colonial history" on long term economic performance as in Acemoglu et al. (2001), we utilize "communist history" as an instrument for transition countries. Our "Independence" dummy identifies whether a country was independent in 1988 or not. One hypothesis is that previously independent countries did not have to reform structural policies quite as profoundly as previously dependent countries (including all of former Yugoslavia) that were forced to start from scratch after independence. Here the fall of the Iron

\footnotetext{
${ }^{5}$ Balcerowicz and Gelb (1995), De Melo et al. (1997), De Melo et al (2001), Fischer et al. (1996a,b), Denizer (1997), and Beck and Laeven (2006) include initial conditions in their analyses.
} 
Curtain provides our first natural experiment. We utilize the initial variation across countries with respect to their need to establish entirely new structural policies in order to identify the impact on income levels, $Y_{i}$ and growth, $\hat{Y}_{i}$. Table 1 shows that Independence is indeed a strong instrument, as indicated by the first stage $\mathrm{R}^{2}$. As expected, the instrument is weaker when used to identify contemporaneous (2001) structural policies, but it remains significant. Note that the positive and significant first stage coefficient indicates that previously independent countries started off with better initial conditions with regard to the quality of structural policies.

Table 1 also shows that the instrumented initial quality of structural policies is highly significant in explaining 2001 income levels as well as 1991-2002 income growth. Initial conditions are thus surprisingly important in explaining long term output levels and subsequent growth rates, which contrast with the findings of De Melo et al. (1997, 2001) and Berg et al. (1999), who argue that the quantitative impact of initial conditions was small and rapidly declining over time. However, the convergence term in the growth regressions is not significant, and structural policies are significant at the 10 percent level only. This leads us to suspect that initial conditions do not capture all determinants of ongoing growth in transition economies.

Table 1: Effects of Initial Conditions and Structural Policies on Income and Growth

\begin{tabular}{|c|c|c|c|c|c|c|}
\hline & Structural Policies 1991 & $Y_{2001}$ & Structural Policies 2001 & $Y_{2001}$ & Structural Policies 1991 & $\hat{Y}_{1991-2001}$ \\
\hline Independence & $\begin{array}{c}0.192 * * * \\
(0.066)\end{array}$ & & $\begin{array}{c}0.184^{* * *} \\
(0.068)\end{array}$ & & $\begin{array}{c}0.143 * * \\
(0.065)\end{array}$ & \\
\hline Structural Policy Index 1991 & & $\begin{array}{c}3.813 * * * \\
(1.102)\end{array}$ & & & & $\begin{array}{l}2.631 * \\
(1.352)\end{array}$ \\
\hline Structural Policy Index 2001 & & & & $\begin{array}{c}3.891 * * * \\
(1.234)\end{array}$ & & \\
\hline$Y_{1991}$ & & & & & $\begin{array}{c}0.122 * * * \\
(0.037)\end{array}$ & $\begin{array}{l}-0.16 \\
(0.315)\end{array}$ \\
\hline $\mathbf{R}^{2}$ & 0.34 & & 0.19 & & 0.45 & \\
\hline $\mathbf{N}$ & 25 & 25 & 26 & 26 & 22 & 22 \\
\hline
\end{tabular}

\section{4) The Importance of Sustained Improvements in Structural Policies}

Cross-sectional analysis in the context of transition and growth suffers drawbacks that limit the insights that can be derived. Given the short time horizon, the initial output decline, and subsequent recovery, the regression analysis should include time trends. In addition, the very nature of those structural policies that changed the economy from plan to market implies that all nations experienced an output drop and a subsequent recovery. This makes it difficult for structural policies to yield an unambiguously positive or negative impact on growth. We thus turn to time series analysis, which derives its power to correlate changes in structural policies with economic growth from the variations in a) the size of the contraction, b) the length of the 
contraction, c) the speed of the recovery, d) the dramatically different growth experiences, and finally e) whether the recovery could be sustained.

The core focus of the paper is thus to identify the impact of ongoing and sustained structural policy improvements on economic growth. A broad feature of Figure 1A is how closely the speed of the recovery and the subsequent plateauing of growth coincide with the initial speed of structural policy change and how long it was sustained. This implies that the transition experience was not one of uniform improvement in structural policies and growth, but that the varied country experiences are actually determined by the ongoing structural policy change. Our hope is that these dynamics assist us in identifying the effect of structural policies on growth in our panel.

The unique advantage of our panel dataset is that we can trace the annual impact of structural change on growth over the eleven-year period. Note that the approach is very different from event studies that examine the effects of structural policies in "transition time," which identifies how long it takes to have sufficiently strong structural policies in place to generate growth after the fall of communism in a country. Instead we utilize the variation from different transition experiences to understand how structural policies affect growth over time. In that sense it is even helpful for us that reforms started in two waves, with Former Soviet Union countries entering transition later. This provides additional variation while controlling for time fixed effects. However we compare our results to transition time results below for completeness.

\section{4a) Time Series Methodology}

To control for variables that do not change over time such as history, geography, and independence, we estimate fixed effects OLS (LSDV) and system-GMM regressions for:

$$
\hat{Y}_{i, t}=\alpha+\beta I_{i, t}+\gamma \ln Y_{i . t-1}+\eta_{i}+v_{t}+\varepsilon_{i, t}
$$

where $\hat{Y}_{i, t}$ is per capital income growth in country $i$ at time $t, I$ is the structural policy index described above, $\alpha$ is a constant, $\eta_{i}$ captures country-specific fixed effects, and $v_{t}$ time fixed effects. The inclusion of time fixed effects ensures that our results are not contaminated by a possible common trend in the variables of interest. Nickell (1981) shows that the LSDV estimator in (1) is biased in a dynamic panel; simulation studies demonstrate that the lagged dependent variable LSDV coefficient is biased downwards, whereas other coefficients are less affected (see Judson and Owen 1999, Gaduh 2002, Hauk and Wacziarg 2004). Kiviet (1995) 
derived a correction for this LSDV bias, which we implement using Bruno's (2005a, b) procedure.

To explore the time-series properties of the data, we conduct a Levin, Lin, and Chu (2002) panel unit root test, which rejects the null hypothesis of a common unit root for both the growth rate and for the structural reform index. In addition, an Im, Pesaran, and Shin (2003) test rejects the null hypothesis of individual unit roots for growth rates and the structural reform index. Following Bond et al. (2001), whenever lagged GDP is included as an explanatory variable, we express the lagged GDP in deviations from time means. This eliminates a common time trend in $\ln Y_{i, t}$ over the eleven-year horizon and renders this variable stationary. Thus all variables entering (1) are stationary when controlling for time fixed effects.

Highly persistent time series may introduce weak instrument bias, in which case the Arellano and Bond (1991) difference-GMM estimator may not be appropriate in the growth context. ${ }^{6}$ The Blundell and Bond (1998) system-GMM estimator alleviates the issue:

$$
\hat{Y}_{i, t}-\hat{Y}_{i, t-1}=\beta \Delta I_{i, t}+\gamma \Delta \ln Y_{i, t-1}+\Delta \nu_{t}+\Delta \varepsilon_{i, t}
$$

As in Arellano and Bond (1991) this estimator uses a difference equation to eliminate constant country-specific fixed effects and $\Delta$ represents a variable's time difference. To identify the coefficients in (2), Blundell and Bond (1998) suggest that lags two and higher of $I_{i, t}$ and $\ln Y_{i, t-1}$ are used as instruments. When measurement error and endogeneity pose additional problems, Bond (2002) suggests longer lags (we thus use lags three to five). To avoid overfitting bias, once the number of instruments increases relative to the number of observations, we restrict the instruments to one for each variable and time lag.

In the presence of highly persistent series, the difference-GMM estimator may be subject to weak instrument bias. Blundell and Bond (1998) show that equation (1) provides additional moment conditions, given the explanatory variables' mean stationarity that can be utilized to estimate the coefficients consistently. These moment conditions use lagged differences of the explanatory variables in (1) as instruments. Since endogeneity and measurement error may pose a potential problem, we use lag two (instead of lag one) as instruments for the moment conditions derived from (1).

Since we control for lagged income, the current growth rate should be influenced only through current structural policies. The three to five year lags then influence growth only through

\footnotetext{
${ }^{6}$ See Hauk and Wacziarg (2004), Bond, Hoeffler, and Temple (2001), Levine, Loayza, and Beck (2000).
} 
their effects on current institutions. The lag structure also hypothesizes that lagged structural policies affect current growth other than through current institutions. The presence of multiple lags allows a test of this exclusion restriction with the help of an over-identification test. We report the results from a Sargan (Hansen J) overidentification test, as well as the Arellano-Bond test for $\mathrm{AR}(2)$ serial correlation in the residuals. Both tests allow an assessment of whether the chosen identification strategy of the system-GMM estimator is valid.

In our discussion we concentrate on the system-GMM coefficients as the most reliable estimates since this method best addresses potential endogeneity bias as outlined in Bond (2002) and Bond, Hoeffler, and Temple (2001). Nevertheless, the Nickell-bias corrected LSDV estimates serve as useful benchmarks and provide country fixed effects. The usual caveat applies that all instrumental variables estimations rely on an "essentially non-testable hypothesis" (Acemoglu 2005). In our approach, we must assume that three- to five-year lagged values are unaffected by current growth and have no direct effect beyond their impact on contemporaneous institutions. Instead of relying only on lag structures, we will also provide an additional theorybased alternative below.

\section{4b) Time Series Evidence}

In Table 2 we first report the coefficient produced by what, in our view, is the most appropriate econometric methodology (system GMM). Across all specifications, the magnitude of the structural policy estimates is surprisingly large. In our baseline specification (column 2), a 10 percent increase in the structural policy index is associated with a 2.68 percent increase in growth. These are sizable growth possibilities that can be reaped from structural policy changes. Large impacts of institutions on economic performance are not new to the literature. Prominent studies by Hall and Jones (1999, p. 105) and Acemoglu et al. (2001, p. 1387) find that 10 percent increases in institutional quality raise long run output levels by roughly 67 percent and 160 percent, respectively. While the coefficients in Table 2 may appear large at first, the magnitude is remarkably robust across different specifications that include interaction terms (columns 3-4, 10, $12,14,16)$, a shorter panel (column 4), the inclusion of macro policy variables that determine growth (column 5), annual growth rates (columns 2-5, 9-10, 13-16), event studies based on "transition time" (columns 9-10), or three-year averaged growth ${ }^{8}$ (columns 11-12). In all

\footnotetext{
${ }^{7}$ At times, the transition literature accounts for different starting dates with event studies. We follow Merlevede's (2003) definition for each country's $t=1$ in which communism and central planning were abandoned.

${ }^{8}$ Averaging is a common robustness test; see, e.g., Acemoglu et al. (2003) or Burnside and Dollar (2000).
} 
specifications the Arellano and Bond AR(2) and the Sargan (Hansen J) tests support our assumption of instrument exogeneity and report no evidence of serial correlation. The exceptions are the three-year averaged results where we judge the dynamic panel to be too short to gain confidence in the instruments. The other exception is the introduction of macro policy variables where the instrumentation with lagged dependent values does not seem to provide good instruments. Acemoglu et al. (2003) point out that this biases results in favor of macro policies.

It is tempting to associate the large impact of structural policies with great strides in early phases of the transition. However, column 5 confirms that if we start the analysis in 1994, the magnitude of the coefficient is just about identical - and its standard error is even slightly smaller. The robustness test that excludes early reform years thus provides evidence that ongoing reforms are more crucial for growth than initial periods of opportunity.

In the cross section (Table 1), initial conditions matter, while the dynamic estimations in Table 2 attribute great explanatory power to ongoing structural change. It is impossible to separate out the individual effects since initial conditions are indistinguishable from country fixed effects in the dynamic panel. We judge this to be an advantage of the panel estimation, since it helps us avoid the lively discussion regarding the correct initial conditions that are to be examined (see De Melo et al., 2001, and Campos and Coricelli, 2002, for excellent surveys). In an effort to relate initial conditions to ongoing structural policy reform and growth, we include a term which interacts the initial 1991 structural policy level with subsequent values. Campos and Coricelli (2002) suggest that such an interaction term highlights the relationship between initial conditions and subsequent structural policy development. There seems to be broad agreement in the literature that the level of initial conditions may affect the intensity of the structural policy changes. ${ }^{9}$ The interaction term is never significant in any GMM specifications, whereas the structural policy index's magnitude and significance remains unchanged throughout. This has three important implications. First, excellent growth can be attained even with unfavorable initial conditions. Second, there exists no "growth bonus" for countries that reformed early. Third, a "growth penalty" does not exist even if reforms start late, as long as they eventually reach sufficient quality. These findings support the robustness results in Table 2, column 4, that ongoing structural policy change matters even when initial years of transition are excluded.

While our general approach follows Hall and Jones (1999) and Acemoglu et al. (2001) in focusing on the impact of institutions only, alternative variables have been suggested in the

\footnotetext{
${ }^{9}$ See, e.g., De Melo et al. (2001), Balcerowicz and Gelb (1995), Aslund (1995), De Melo, Denizer, and Gelb (1997), and Aslund, Boone, and Johnson (1996).
} 
literature to also determine economic performance in transition economies. Consensus variables include the fiscal deficit, government consumption, and inflation. ${ }^{10}$ As an additional robustness check we add these variables to the regressions. Structural policy and the fiscal deficit are significant; however, government consumption is not. Structural policies are highly correlated with inflation (column 8), which rules out a strategy to include both in one regression.

As further robustness results, we offer the Kiviet (1995) bias-corrected LSDV results (columns 13-14) and as well those based on the original Arellano-Bond (1991) difference-GMM estimator that allows for shorter lags (one to three) as instruments (columns 15-16). In terms of significance, the results are just about identical to the System-GMM results; however, the estimates are slightly higher, reflecting the biases discussed in Section 4a.

As in previous empirical analyses of transition economies, country fixed effects are prominent in the dynamic panel. Fixed effects range from 0.18 (Slovenia) to -0.2 (Tajikistan). The difference between the highest and lowest country's fixed effect is almost 0.4 , and therefore considerably larger than the LSDV coefficient on structural policies. Hence not only structural change, but also the influence of fixed effects on growth is considerable. We can only conjecture about the sources of the fixed effects. The correlation between fixed effects and the Fidrmuc (2001) "Distance to Brussels" measure is surprisingly large (-0.73), indicating that close proximity to the EU generated a significant growth bonus. ${ }^{11}$ Such a bonus could be explained by a multitude of causes ranging from the EU-accession-induced institutional changes to simple gravity or multinational entry/production diversification decisions. The correlation between fixed effects and the quality of initial structural policies is of the same magnitude (0.62), indicating that initially better structural policies potentially exert a level effect on subsequent growth. These two variables exhaust by no means all possible interpretations of the fixed effects estimates. The goal of our dynamic panel analysis is solely to show that even short-term changes in structural policies can substantially impact growth after fixed factors have been taken into account.

A key robustness exercise is to examine whether these results hold up to alternative measures for structural policies. Table 3 reports the results for our ICRG-based Rule of Law measure which is perhaps closer and more narrowly focused on institutional change. Since the structural change and Rule of Law measures are normalized in identical fashion, their coefficients can be readily compared. The results are just about identical in terms of significance

\footnotetext{
${ }^{10}$ It is common to treat macro policy variables as exogenous in the literature. The GMM methodology also instruments for macro variables using lags.

${ }^{11}$ Interestingly the -0.44 correlation with "Distance to Moscow" is neither positive, nor as large as one might expect.
} 
and magnitude. A 10 percent increase in the Rule of Law index toward OECD levels increases growth by 2.4 percent (column 2). Again the estimates are remarkably robust in terms of economic and statistical significance across all different specifications that include shorter panels (column 4), the inclusion of macro policy variables that determine growth (column 5-6), annual growth rates (columns 2-6, 9-10, 13-16), event studies based on "transition time" (columns 910), or three-year averaged growth (columns 11-12). Even the same bias pattern can be observed in the LSDV and difference GMM regressions (columns 13-16) as in Table 2. We also include a specification that includes macro policy variables, Rule of Law, and structural policies (column 6) to show the independent effects of either institutional variable even in the presence of macro policy determinants. One important difference exists between Tables 2 and 3. For all regressions with interactions between initial levels and subsequent changes in the Rule of Law, both estimates are not significant. This is most likely due to a high degree of multicollinearity. Initial Rule of Law varied from 0.1 to 0.9 in 1991 while it varied only from 0.1 to 0.4 for structural policies. Hence in the Rule of Law regressions we cannot disentangle the separate effects of initial conditions and ongoing change. However, the regressions do show that even after controlling for initial Rule of Law with fixed effects, ongoing changes in Rule of Law are highly significant.

\section{5) Alternative Instruments: The Hierarchy of Institutions Hypothesis}

The previous section has shown that economic institutions have a large causal effect on growth when lagged values of institutions are used as instruments. This section explores an alternative identification strategy that relies not on lagged values, but on a clear structurally formulated hypothesis and a formal two stage estimation process to identify the effect of structural policies on growth. Acemoglu et al. (2005) clearly outlined those political institutions that allocate excessive power to an individual (or a small group) to render it unlikely that structural policies are sustained to protect property rights for all. The authors describe a chain of events where political institutions determine the distribution of de jure political power, which in turn affects the choice of structural policies ("economics institutions" in their terminology). This framework is introduced as a hierarchy of institutions, where political institutions influence equilibrium structural policies, which then determine economic outcomes. ${ }^{12}$

\footnotetext{
12 A large literature has analyzed the importance of political institutions for economic development. See, e.g., Acemoglu (2003), Acemoglu and Johnson (2005), Acemoglu et al. (2005), Persson (2004), Rigobon and Rodrik (2005), Keefer (2005), and Beck and Laeven (2006).
} 
Acemoglu et al. (2005) summarize examples of political institutions as "democracy vs. dictatorship or autocracy, and the extent of constraints on politicians and political elites." Acemoglu and Johnson (2005) motivate the Polity IV variable "Executive Constraints" as "conceptually attractive since it measures institutional and other constraints that are placed on presidents and dictators. Theoretically, we expect a society where elites and politicians are effectively constrained to experience less infighting between various groups to take control of the state, and to pursue more sustainable policies." This certainly applies directly to our transition countries were successful structural policies can be seen as the outcome of effective political participation. Acemoglu and Johnson (2005) also address specifically how Executive Constraints are uniquely applicable to transition economies and our natural experiment. In societies with weak constraints on rulers, "[f]ollowing a change in the balance of political power, groups that gain politically may then attempt to use their new power to redistribute assets and income to themselves, in the process creating economic turbulence. In contrast, this source of turbulence would be largely absent in societies where institutions prevent this type of redistribution." And "politicians may be forced to pursue unsustainable policies in order to satisfy various groups and remain in power, and volatility may result when these policies are abandoned." Acemoglu et al. (2005) note also, however, the common caveat that empirics cannot distinguish between the exact channels that link political institutions to structural policies.

Alternative measures are proposed by Keefer (2005) who argues that the "Check and Balances" index and the "Executive Indices of Electoral Competitiveness" from the World Bank database of political institutions (Beck et al. 2001) are better variables to gage the effects of political institutions on growth. Keefer (2005) argues that Checks and Balances capture the essential ingredients necessary for secure property rights: elections and checks on the executive branch. However, unlike the Polity IV Executive Constraints measure, Keefer (2005) argues, Checks and Balances captures only the formal constraints that theory predicts should protect property rights, not whether those formal constraints are binding in practice. Electoral Competitiveness is employed by Keefer (2005) to reflect that political systems in which government turnover is competitive make it harder for special interests to "capture" the government and/or the state as a whole (see also Hoff et al. 2005). Persson, Roland, and Tabellini (2000) refine the concept further by specifying whether the executive is subject to a confidence requirement in the legislature to distinguish between the type of democracy and the resulting structural policies. Their Type of Democracy variable is not available for transition economies; we proxy it with the Polity IV Democracy variable. 
Political institutions are not entirely exogenous either, however. They change slowly and Acemoglu et al. (2005) point out that societies change their constitutions during transitions from dictatorship to democracy to modify Executive Constraints. It is hard to argue, however, that lagged political institutions affects subsequent year-to-year output growth. For one, the hierarchy of institution hypothesis clearly outlines that political changes first affect structural policies and then output. No exact test can reveal how long the time lag is, however; the ultimate test is that neither variable possesses a direct effect on output as seen in columns 8-10 in Table 4. We also perform a Sargan test, which supports our assumption of exogeneity. Theoretical and empirical support for our choice of instruments is also provided by a prominent strand of the transition literature which hypothesizes about extensive links between political transition and the intensity of economic institution reform (although not necessarily output changes) ${ }^{13}$

Table 4: Dynamic Effects of Institutions on Growth

\begin{tabular}{|c|c|c|c|c|c|c|c|c|c|}
\hline & 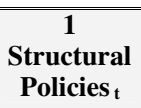 & $\hat{Y}_{1992-2001}^{2}$ & $\begin{array}{c}3 \\
\text { Structural } \\
\text { Policies }_{\mathrm{t}}\end{array}$ & $\hat{Y}_{1992-2001}^{4}$ & $\begin{array}{c}5 \\
\text { Structural }^{\text {Policies }} \\
\text { t }_{\mathrm{t}}\end{array}$ & $\hat{Y}_{1992-2001} \mathbf{6}$ & \begin{tabular}{c}
\multicolumn{7}{c}{$\mathbf{7}$} \\
$\hat{Y}_{1992-2001}$
\end{tabular} & $\hat{Y}_{1992-2001} \mathbf{8}$ & $\hat{Y}_{1992-2001}^{9}$ \\
\hline $\begin{array}{l}\text { Structural } \\
\text { Policy Index }\end{array}$ & & $\begin{array}{l}0.177 * \\
(0.103)\end{array}$ & & $\begin{array}{c}0.346 * * \\
(0.136)\end{array}$ & & $\begin{array}{l}0.262 * \\
(0.141)\end{array}$ & & & \\
\hline $\begin{array}{l}\text { Executive } \\
\text { Constraints }_{t-1}\end{array}$ & $\begin{array}{c}0.254 * * * \\
(0.059)\end{array}$ & & & & & & $\begin{array}{l}-0.053 \\
(0.176)\end{array}$ & & \\
\hline $\begin{array}{l}\text { Executive } \\
\text { Election }_{\text {Competition }_{\mathrm{i}-1}}\end{array}$ & & & $\begin{array}{l}0.039 * \\
(0.021)\end{array}$ & & & & & $\begin{array}{c}0.011 \\
(0.086)\end{array}$ & \\
\hline $\begin{array}{l}\text { Checks and } \\
\text { Balances }_{t-1}\end{array}$ & & & $\begin{array}{l}-0.006 \\
(0.005)\end{array}$ & & & & & $\begin{array}{c}0.001 \\
(0.021)\end{array}$ & \\
\hline Democracy $_{t-1}$ & & & & & $\begin{array}{l}0.007 * * * \\
(0.002)\end{array}$ & & & & $\begin{array}{c}0.014 \\
(0.015)\end{array}$ \\
\hline$Y_{t-1}$ & $\begin{array}{l}-0.024 \\
(0.027)\end{array}$ & $\begin{array}{l}-0.045 \\
(0.031)\end{array}$ & $\begin{array}{l}-0.068 * \\
(0.039)\end{array}$ & $\begin{array}{c}-0.081 * * \\
(0.035)\end{array}$ & $\begin{array}{l}-0.033 \\
(0.027)\end{array}$ & $\begin{array}{l}-0.061 \\
(0.038)\end{array}$ & $\begin{array}{c}0.009 \\
(0.033)\end{array}$ & $\begin{array}{l}-0.015 \\
(0.039)\end{array}$ & $\begin{array}{l}-0.061 \\
(0.059)\end{array}$ \\
\hline $\begin{array}{l}\text { Sargan overid } \\
\text { p-value }\end{array}$ & & 0.474 & & 0.670 & & 0.574 & 0.624 & 0.994 & 0.685 \\
\hline $\begin{array}{l}\text { AR(2) test } p \text { - } \\
\text { value }\end{array}$ & & 0.913 & & 0.808 & & 0.908 & 0.239 & 0.421 & 0.896 \\
\hline $\mathrm{R}^{2}$ & 0.83 & & 0.74 & & 0.82 & & & & \\
\hline $\mathrm{N}$ & 241 & 241 & 200 & 200 & 245 & 245 & 241 & 200 & 245 \\
\hline
\end{tabular}

The hierarchy of institutions approach is implemented in Table 4 using both LSDV and GMM. The LSDV regressions show the strength of the instrument in a mimic first stage, and the system-GMM then delivers unbiased second stage coefficients. To investigate the strength of the instruments, we regress structural policies on the various political institutions that were motivated above, together with time fixed effects (column 2,4,6). The goodness of fit in the first stages is substantial; the political institutions are all significant with the exception of Checks and Balances in the Keefer (2005) motivated specification (column 3). Together with fixed effects

\footnotetext{
${ }^{13}$ See e.g., Balcerowicz and Gelb (1995), De Melo, Denizer, and Gelb (1997), Aslund, Boone, Johnson (1996).
} 
and lagged income, political institutions account for between 74 to 83 percent of the variation in economic institutions. The F-tests reject the null-hypothesis of no explanatory power of all regressors at the one percent level. These results show the interdependence of political institutions and structural policies and are thus important confirmations of the hierarchy of institutions hypothesis.

Having established sufficiently strong instruments, we present the instrumented systemGMM structural policy estimates of (1) in Table 4. Here we use the instrument in the level equations only. The coefficients on structural policies using the hierarchy of institutions as identification are exactly in line with the ones observed in Tables 2 and 3. While structural policies are slightly less significant (as compared to the System-GMM coefficients using lags in Tables 2 and 3), we take this as important, independent support of the significant effects of ongoing structural change on growth. Both the Sargan overidentification test and the AR(2) test of the residuals provide support for this identification strategy.

\section{8) Conclusion}

Transition economies offer a unique natural experiment to assess the impact of structural policy changes on economic growth. Two alternative approaches that control for the endogeneity of structural policy and time fixed effects find similar strong economically and statistically significant impact. A 10 percent improvement of structural policies toward OECD standards increases subsequent growth by about 2.7 percent. The magnitude of the result is robust to variations in the length of the panel, to event studies in transition time, to averaged growth rates as dependent variables, and to the inclusion of alternative public policy variables. Examining the interaction between initial and subsequent structural policies allows us to show that early (late) movers do not incur a growth bonus (penalty). To test robustness, we construct the first complete time series for an ICRG based Rule of Law indicator in transition countries (using Campos, 2000 and ICRG data). Here results are just about identical in terms of magnitude and significance.

Our results show more than the importance of institution for a specific set of countries. We replicate the results that institutions matter in the long run, but more importantly we are able to document the contemporaneous effect of institutional change on economic growth. This should be comforting for policy makers. Economic institutional reform can lead to rapid growth benefits; it does not have to take decades for the effects to show. Our use of multiple estimation techniques, all of which generate comparable results in terms of economic and statistical 
significance, highlights the power of this natural experiment to track institutional change across a sizeable number of countries.

\section{References}

Acemoglu, D. (2003). "Why not a Political Coase Theorem? Social Conflict, Commitment and Politics." Journal of Comparative Economics, 31(4), pp. 620-652.

--- (2005) "Constitutions, Politics and Economics: A Review Essay on Persson and Tabellini's

"The Economic Effects of Constitutions." Journal of Economic Literature, 43(4), 1025-1048.

Acemoglu, D., and S. Johnson (2005). "Unbundling Institutions." JPE, 113(5), pp. 949-995.

Acemoglu, D., S. Johnson, and J. Robinson (2001). "The Colonial Origins of Comparative Development: An Empirical Investigation." AER, 91(5), pp. 1369-1401.

--- (2002). "Reversal of Fortune: Geography and Institutions in the Making of the Modern World of Income Distribution." Quarterly Journal of Economics, 117(4), pp. 1231-94.

--- (2005). "Institutions as the Fundamental Cause of Long-Run Growth." in: Aghion, P., and S. Durlauf (eds.). Handbook of Economic Growth, pp. 385-472. Amsterdam: North Holland.

Acemoglu, D., S. Johnson, J. Robinson, and Y. Thaicharoen (2003). "Institutional Causes, Macroeconomic Symptoms: Volatility, Crises, and Growth.” JME, 50(1), pp. 49-123.

Aghion, P., and O. Blanchard (1994). "On the Speed of Transition in Central Europe." in: Fischer and Rotemberg (eds.) NBER Macroeconomic Annual 1994, pp. 283-320.

Arellano, M., and S. Bond (1991). "Some Tests of Specification for Panel Data: Monte Carlo Evidence and an Application to Employment Questions." RES, 58(2), pp. 277-297.

Aslund, A., P. Boone, and S. Johnson (1996). "How to Stabilize: Lessons from Post-communist Countries". Brookings Paper on Economic Activity, No. 1, pp. 217-91.

Balcerowicz, L., and A. Gelb (1995). "Macropolicies in Transition to a Market Economy: A Three-Year Perspective". Proceedings of the World Bank Annual Conference on Development Economics, 1994, pp. 21-44.

Barro, R. (1997). Determinants of Economic Growth: A Cross-country Empirical Study. Cambridge and London: MIT Press.

Beck, T., G. Clarke, A. Groff, P. Keefer, and P. Walsh (1991). "New Tools in Comparative Political Economy: The Database of Political Institutions" World Bank Economic Review, 15, pp. 165-76.

Beck, T., and L. Laeven (2006): "Institutions Building and Growth in Transition Economies." Journal of Economic Growth, 11(2), pp. 157-186.

Berg, A., E. Borensztein, R. Sahay, and J. Zettelmeyer (1999). "The Evolution of Output in Transition Economies: Explaining the Differences." IMF Working Paper WP/99/73.

Blanchard, O (1997). The Economics of Post-Communist Transition. Oxford University Press: Oxford.

Blanchard, O., and M. Kremer (1997). “Disorganization.” QJE, 112(4), pp. 1091-1126.

Blundell, R., and S. Bond (1998). "Initial Conditions and Moment Restrictions in Dynamic Panel Data Models." Journal of Econometrics, 87(1), pp. 115-43.

Bond, S. (2002). "Dynamic Panel Data Models: A Guide to Micro Data Methods and Practice." Portuguese Economic Journal, 1(2), pp. 141-162.

Bond, S., A. Hoeffler, and J. Temple (2001). "GMM Estimation of Empirical Growth Models." CEPR Discussion Paper No. 3048.

Bruno, G. (2005a). "Approximating the Bias of the LSDV Estimator for Dynamic Unbalanced Panel Data Models." Economics Letters, 87, pp. 361-366.

--- (2005b). "Estimation and Inference in Dynamic Unbalanced Panel Data Models with a Small Number of Individuals." CESPRI Working Paper no. 165, CESPRI, Bocconi.

Burnside, C., and D. Dollar (2000). “Aid, Policies, and Growth.” AER, 90(4), pp. 847-868. 
Campos, N. (2000) "Context Is Everything: Measuring Institutional Change in Transition Economies" World Bank Policy Research Working Paper 2269.

Campos, N., and F. Coricelli (2002). "Growth in Transition: What We Know, What We Don't, and What We Should.", Journal of Economic Literature, 40(3), pp. 793-836.

De Melo, M., C. Denizer, and A. Gelb (1997). "From Plan to Market: Patterns of Transition" in Blejer, M. and M. Škreb: Macroeconomic Stabilization in Transition Economies. Cambridge: Cambridge University Press, pp. 17-72.

De Melo, M., C. Denizer, A. Gelb, S. Tenev (2001). "Circumstance and Choice: The Role of Initial Conditions and Policies in Transition Economies." The World Bank Economic Review, 15,1,pp.1-31.

Denizer, C. (1997). "Stabilization, Adjustment, and Growth Prospects in Transition Economies." World Bank Policy Research Paper No. 1855.

EBRD, (1994). Transition Report: Infrastructure. London: EBRD.

EBRD, (2000 - 2002, 2005). Transition Report. London: EBRD.

Falcetti E., M. Raiser, and P. Sanfey (2002). "Defying the Odds: Initial Conditions, Reforms and Growth in the First Decade of Transition." Journal of Comparative Economics, 30(2), 22950 .

Fidrmuc, J. (2001). "Forecasting Growth in Transition Economies: A Reassessment" mimeo.

Fisher, S., R. Sahay, and C. Vegh (1996a). "Economies in Transition: The Beginnings of Growth". American Economic Review, 86(2), pp. 229-33.

--- (1996b). "Stabilization and Growth in Transition Economies: The Early Experience". Journal of Economic Perspectives, 10(2), pp. 45-66.

Fischer, S., and R. Sahay (2004). "Transition Economies: The Role of Institutions and Initial Conditions." Festschrift in Honor of Guillermo A. Calvo.

Gaduh, A. (2002). "Properties of Fixed Effects Dynamic Panel Data Estimators for a Typical Growth Dataset" CSIS Working Paper Series WPE 062.

Ghosh, A. R. (1997). "Inflation in Transition Economies: How much and Why?" IMF WP/97/80.

Hall, R., and C. I. Jones (1999). "Why Do Some Countries Produce So Much More Output Per Worker Than Others?" Quarterly Journal of Economics, 114(1), pp. 83-116.

Hauk, W., and R. Wacziarg (2004). "A Monte Carlo Study of Growth Regressions." NBER Technical Working Paper 296.

Havrylyshyn, O., and R. van Rooden (2003). "Institutions Matter in Transition, But So Do Policies." Comparative Economic Studies, 45(1), pp. 2-24.

Havrylyshyn, O., R. van Rooden, and I. Izvorski (1998). "Recovery and Growth in Transition Economies: A Stylized Regression Analysis." IMF Working Paper, 98/141.

Hellman, J. (1998). "Winners Take All: The Politics of Partial Reform in Postcommunist Transitions." World Politics, 50(2), pp. 203-234.

Heybey, B., and P. Murrell (1999). "The Relationship between Economic Growth and the Speed of Liberalization during Transition". Journal of Policy Reform, 3(2), pp. 121-37

Hoff, K., S. Horowitz, and B. Milanovic (2005). "Political Alternation, Regardless of Ideology, Diminishes Influence Buying: Lessons from Transitions in Former Communist States." Carnegie Endowment for International Peace, Policy Outlook. January 2005.

Im, K., M. Pesaran, and Y. Shin (2003). "Testing for Unit Roots in Heterogeneous Panels." Journal of Econometrics, 115(1), pp. 53-74 .

IMF (2000). World Economic Outlook: Focus on Transition Economies. Washington, DC: IMF. Judson, R., and A. Owen (1999). "Estimating Dynamic Panel Data Models: A Guide for Macroeconomists." Economics Letters, 65(1), pp. 9-15. 
Keefer, P., (2005), "Beyond Legal Origin and Checks and Balances: Political Credibility, Citizen Information and Financial Sector Development" Paper presented at the Conference: "Economics, Political Institutions and Financial Markets", Stanford University

Kiviet, J. (1995). "On Bias, Inconsistency, and Efficiency of various estimators in Dynamic Panel Models". Journal of Econometrics, 68(1), pp. 53-78.

Knack, S., and P. Keefer (1995). "Institutions and Economic Performance: Cross-Country Tests Using Alternative Institutional Measures”. Economics and Politics, 7(3), pp. 207-27.

Kornai, J. (1994). "Transformational Recession: The Main Causes." Journal of Comparative Economics, 19(1), pp. 39-63.

Krasner, S.D. (1993). "Approaches to the State: Alternative Conceptions and Historical Dynamics". Comparative Politics, 16(2): 223-46.

Levin, A., C. Lin, and C. Chu (2002). "Unit Root Tests in Panel Data: Asymptotic and FiniteSample Properties". Journal of Econometrics, 108(1), pp. 1-24.

Levine, R., N. Loayza, and T. Beck (2000): "Financial Intermediation and Growth: Causality and Causes." Journal of Monetary Economics, 48, pp. 31-77.

Merlevede, B. (2003). "Reform Reversals and Output Growth in Transition", Economics of Transition, 11(4), pp. 649-667.

Murrell, P. (1996). "How Far Has the Transition Progressed?” JEP, 10(2), pp. 25-44.

Nickell, S. (1981) "Biases in Dynamic Models with Fixed Effects" Econometrica, 49, 6, 141726.

North, D. (1990). Institutions, Institutional Change and Economic Performance. Cambridge: Cambridge University Press.

Norris, P., (1997), "Choosing Electoral Systems: Proportional, Majoritarian and Mixed Systems”. International Political Science Review, 18(3), pp. 297-312.

Persson, T. (2004). “Consequences of Constitutions.” JEEA 2 (1), pp. 139-161.

--- (2005). "Forms of Democracy, Policy and Economic Development". Working Paper. Version of January 2005.

Persson, T., G. Roland, and G. Tabellini (2000). "Comparative Politics and Public Finance". Journal of Political Economy, 108(6), pp. 1121-61.

Rigobon, R., and D. Rodrik (2005). "Rule of Law, Democracy, Openness, and Income: Estimating the Interrelationships.” Economics of Transition, 13( 3), pp. 533-64.

Rodrik, D, A. Subramanian, and F. Trebbi (2004). "Institutions Rule: The Primacy of Institutions over Geography and Integration in Economic Development." Journal of Economic Growth, 9(2), pp. 131-65.

Roland, G. (2000). Transition and Economics: Politics, Markets and Firms. MIT Press.

--- (2004). "Fast-Moving and Slow-Moving Institutions", CESifo DICE Report, pp. 16-21.

--- (2005). "After Enlargement: Institutional Achievements and Prospects in the New Member States." Proceedings of the Third ECB Conference "The New EU Member States: Convergence and Stability"

Selowsky, M., and R. Martin (1997). "Policy Performance and Output Growth in the Transition Economies". American Economic Review, 87(2), pp. 349-353.

Williamson, O. E. (2000), "The New Institutional Economics: Taking Stock, Looking Ahead", JEL, 38(3), pp. 595-613.

Wolf, H. C. (1999). “Transition Strategies: Choices and Outcomes." Princeton Studies in International Finance No. 85. 


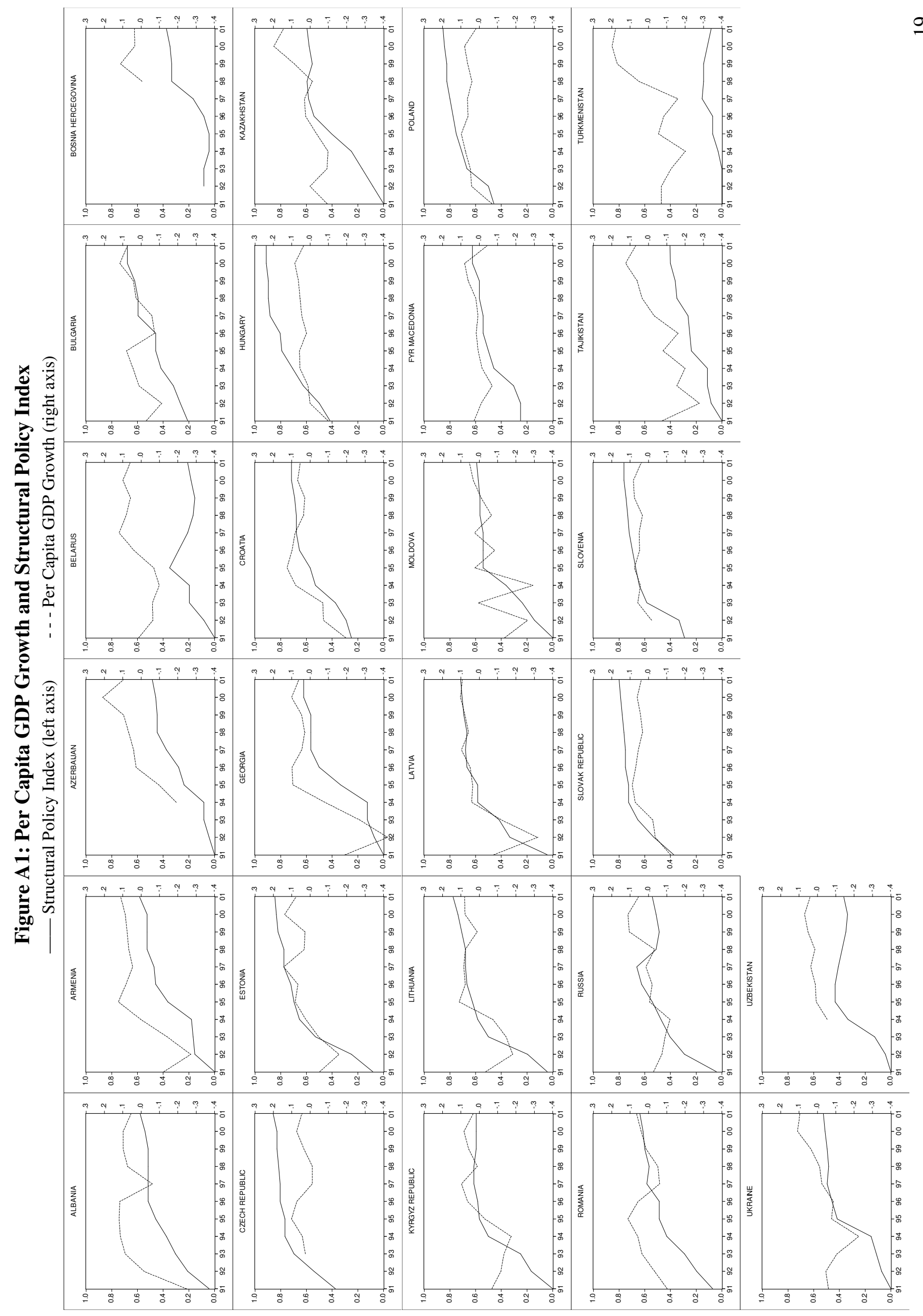



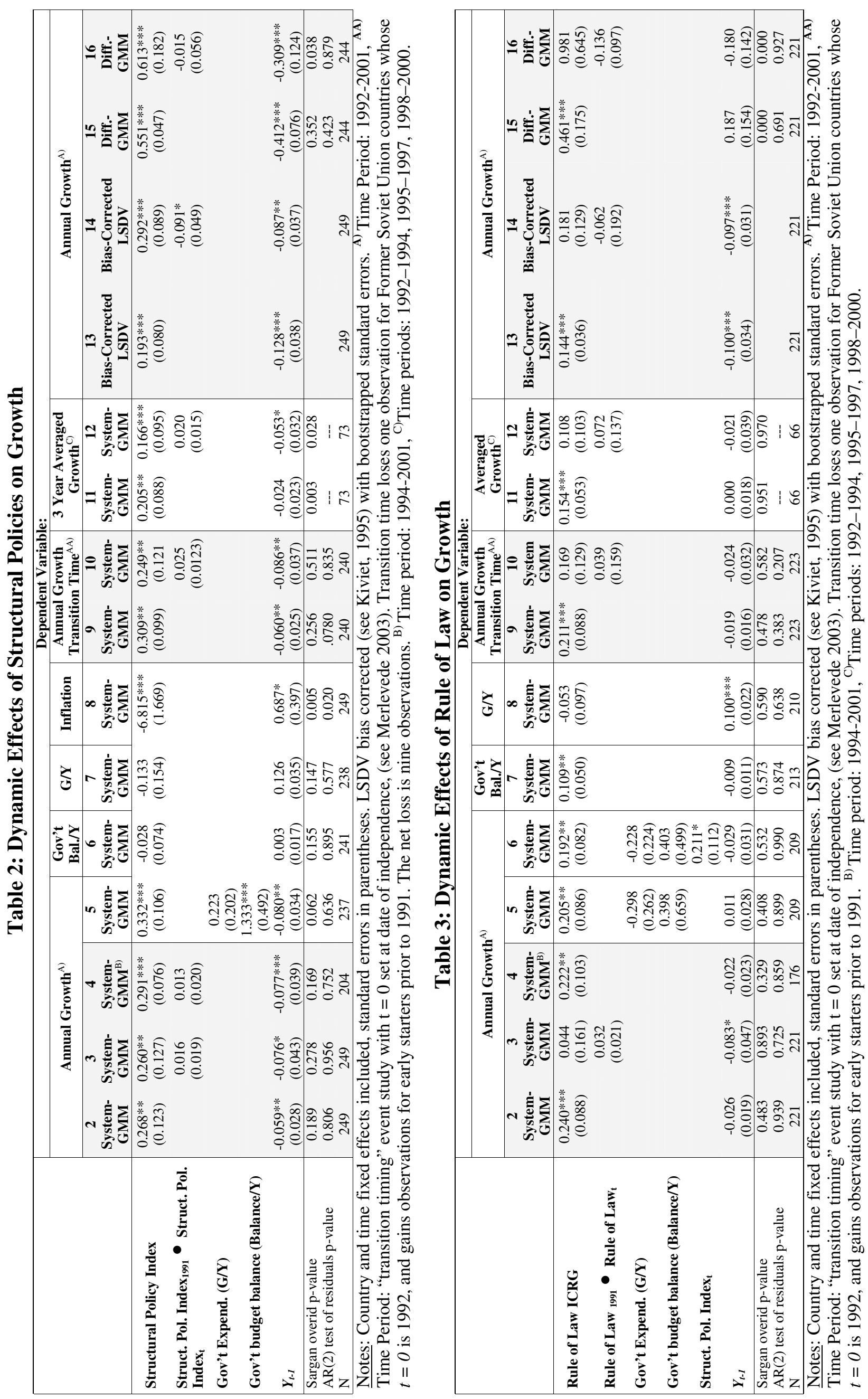